* Pós-doutorando em Direito pela University of Ljubljana (Eslovênia) e Università di Pisa (Itália). Pós-doutor pela Università degli Studi de Messina (Itália) e Universidade de Coimbra (Portugal). Doutor em Direito pela Universidade Gama Filho (UGF). Mestre em Direito pela Faculdade de Direito Milton Campos (FDMC). Professor de Graduação e Mestrado da Universidade de Itaúna (UIT) e do Instituto de Ensino Superior Presidente Tancredo de Almeida Neves (IPTAN). E-mail: deilton.ribeiro@terra. com.br.

** Mestre em Filosofia pela Universidade Federal de Ouro Preto (UFOP). Graduado em Direito pela Faculdade de Direito Conselheiro Lafaiete (FDCL). Professor do Instituto Federal de Minas Gerais (IFMG), Campus Ouro Branco. E-mail: leandrojosesm@ gmail.com.

\section{O Princí́ío do Pleno Emprego: a FunÇão Solidária e Sustentabilidade DAS SOCIEDAdES EMPRESÁRIAS}

\author{
The Full EMPloyment Principle: \\ THE Social Role of Solidary and \\ Sustainability of COMPANIES
}

\section{Deilton Ribeiro Brasil* Leandro José de Souza Martins**}

Como citar: BRASIL, Deilton Ribeiro; MARTINS, Leandro José de Souza. O princípio do pleno emprego: a função solidária e sustentabilidade das sociedades empresárias. Scientia Iuris, Londrina, v. 21, n. 1, p.212-244, mar. 2017. DOI: $10.5433 / 2178-8189.2017 \mathrm{v} 21$ n1p212. ISSN: 2178-8189.

Resumo: Este artigo tem por escopo analisar o princípio da busca do pleno emprego sob a ótica da função solidária e sustentabilidade das sociedades empresárias, no contexto da Lei $\mathrm{n}^{\circ} 11.101$, de 9 de fevereiro de 2005.0 objetivo da lei de recuperação judicial e de falências é, dentre outros, o de permitir a adoção de mecanismos que, pondo em relevo os aspectos inequivocadamente institucionais das empresas viáveis, busquem sua reorganização e recuperação econômica. Consequentemente, haverá, com isso, preservação de empregos, sem prejuízo da produção e circulação de mercadorias e riqueza. De fato, o exercício da 
atividade empresária é fonte de arrecadação de impostos e de empregos, constituindo-se em instrumento fundamental para a progressiva eliminação das desigualdades socioeconômicas, da pobreza e contribui ainda, para a melhoria das condições de trabalho e fomento da atividade econômica. A pesquisa é de natureza teóricobibliográfica seguindo o método descritivoanalítico, que instruiu a análise da legislação constitucional e a infraconstitucional, bem como a doutrina que informa os conceitos de ordem dogmática.

Palavras-chave: Busca do pleno emprego. Sustentabilidade. Função solidária da empresa. Falência. Recuperação de empresas.

Abstract: This paper analyzes the full employment principle with the social roles of solidary and sustainability within companies and corporations, in the scope of the Brazilian Law $n^{\circ}$. 11.101 of February 9, 2005. The endgoal of this law - also known as the law of bankruptcy and judicial reorganization - is to institutionalize the adoption of mechanisms that emphasizes the various aspects and functionality of viable companies. In this fashion, it seeks the reorganization and financial recovery of bankrupt juridical entities; moreover, it intends to maintain current jobs, production and circulation of goods. Bearing in mind that the private sector is a huge source of tax revenue and jobs, it is also an important instrument in the progressive elimination of 
socio-economic inequalities and poverty; improves labor conditions; and promotes economic activity. This study utilizes the literature and bibliographical research method; the descriptive-analytical method, which is important in the analysis of constitutional and subconstitutional laws; as well as doctrines that inform the concepts of dogmatic order.

Keywords: Full employment principle. Sustainability. Social role of solidary. Bankruptcy. Financial recovery of companies. 


\section{INTRODUÇÃO}

No Direito Brasileiro, especialmente com o Código Civil atual, em seu artigo 966, a empresa é entendida como uma atividade profissional, organizada em elementos econômicos, na produção e circulação de bens e serviços. Efetivamente, a empresa é vista como um sistema em que se desenvolvem diversas atividades que partem do âmbito econômico, mas que o extrapolam. De fato, a empresa cumpre, verdadeiramente, relevante papel social ao criar empregos, diretos ou indiretos, tão importantes para que as demais atividades sejam executadas satisfatoriamente, ao lado da produção de bens e serviços, fazendo circular o capital e gerando a arrecadação tributária para o Estado.

Desde as primeiras monografias sobre o conceito de empresa adotado pelo Código Civil, especialmente seguindo o raciocínio de Coelho (2005a, p. 12) e Cavallazzi Filho (2006, p. 51), destaca-se que a atividade econômica da sociedade empresária passou por um processo de evolução. Ou seja, evoluiu ao superar a marcante fase da teoria dos atos de comércio, vista como instrumento de objetivação do tratamento jurídico da atividade mercantil, para estabelecera fase da teoria da sociedade empresária. Esta, por sua vez, possui o acento tônico no caráter subjetivo da empresa, além do fundamental deslocamento da noção de ato para a noção de atividade).

Em nome de tal evolução, portanto, o direito de empresa deixou de ser apenas o direito de certa categoria de profissionais, organizados em corporações próprias, para se tornar a disciplina de um conjunto de atos, que, em princípio, poderiam ser praticados por qualquer cidadão.

Souza (2003, p. 288) verifica que outro ponto referencial resultante dessa evolução consiste em situar a sociedade empresária 
na vida econômica, como ente determinante ou como agente executivo da política econômica. Como tal, a empresa se mostra empenhada no cumprimento dos princípios ideológicos que norteiam toda a ordem jurídico-econômica de uma nação. Especificamente, significa dizer que cabe à empresa a responsabilidade de contribuir, de modo efetivo, para o progresso econômico da sociedade e do Estado. Eum dos modos mais imediatos é com a oferta de trabalho e emprego.

Nas palavras de Azevedo, fundamentando o argumento exposto,

[...] o estabelecimento de uma ordem econômica, que tem por objetivo a realização da justiça social por intermédio da proteção do consumidor, da busca do pleno emprego, da redução das desigualdades sociais, etc., condiciona não apenas a ação do Estado, mas as ações de toda sociedade, principalmente dos titulares das empresas (AZEVEDO, 2008, p. 43).

Notadamente em nossos dias, faz-se urgente a preservação dos empregos, com sua devida remuneração e trabalho. Empregado, o indivíduo tem condições de se realizar economicamente. Por conseguinte, com as mesmas proporções, cada cidadão enxerga melhores possibilidades para sua vida, ou, no mínimo, sabe-se possuidor de garantias básicas para seu sustento e bem-estar.

Ora, em tempos de crise, a empregabilidade é um dos elementos sociais que mais se fragiliza. Atualmente, vê-se que a economia brasileira se encontra afastada de uma oferta ampla/pacífica de emprego: é evidente o quanto que, nos últimos meses, avançaram os números estatísticos que aferem o crescimento do desemprego, ao lado de indicadores referentes ao mercado informal, ou subocupação e subempregos. Infelizmente, há a percepção de baixos salários e rendimentos médios baixos, que 
não condizem com uma situação de dignidade e em consonância às expectativas de direito criadas pelos princípios constitucionais vigentes.

Não obstante tal horizonte, e em confronto direto contra ele, a atividade empresária é importantíssima enquanto personagem direta para implementação do desenvolvimento social. Conforme Sanches; Silveira (2013, p. 121) afirmam:

Várias das atividades outrora exclusivamente estatais (saúde, educação, transporte, previdência) foram transferidas aos titulares da livre iniciativa econômica. Doravante, o acesso a bens essenciais não é feito na qualidade de cidadão social, mas sim como consumidor de serviços concedidos pelo poder estatal.

De qualquer modo, interpreta-se teleologicamente que a empresa atua como um instrumento de concretização dos direitos humanos e de melhoria na qualidade de vida das pessoas, especialmente na questão do emprego, de sua mantença e fomento. Decorre, daí que, a preservação da atividade empresária se mostra, conforme detalhado abaixo, efetiva política de implantação e de preservação do emprego (CASTRO, 2007, p. 43), garantindo, portanto, as relações empresariais, mercantis e produtivas, realizadas entre os mais diversos sujeitos.

Em vista destes elementos, este artigo procura apresentar uma analisar a ótica da função solidária e sustentabilidade das sociedades empresárias à luz do princípio da busca do pleno emprego.

O método utilizado para a realização do trabalho foi descritivoanalítico com a abordagem de categorias consideradas fundamentais para o desenvolvimento do tema - como o princípio do pleno emprego em relação a função solidária e a sustentabilidade das sociedades empresárias. 
A fonte primeira da pesquisa é a bibliográfica que instruiu a análise da legislação constitucional e a infraconstitucional, bem como a doutrina que informa os conceitos de ordem dogmática.

\section{DO EMPREGO ${ }^{1}$ E DO PRINCÍPIO DO PLENO EMPREGO À LUZ DA EMPRESA}

\subsection{O Princípio do Pleno Emprego}

A partir da Constituição Federal de 1988, o princípio da busca do pleno emprego se tornou consagrado no ordenamento brasileiro, substituindo em nomenclatura e expansão o princípio da expansão das oportunidades de emprego produtivo. O pleno emprego, assim, apresentase como um dos princípios da Ordem Econômica da CF/1988, cujo objetivo maior e a promoção da existência digna dos cidadãos, segundo os ditames da Justiça Social.

O princípio da busca do pleno emprego pode ser classificado, segundo a tipologia apresentada por Canotilho (2004) como princípio constitucional impositivo, impondo ao legislador "[...] a realização de fins e a execução de tarefas. São, portanto, princípios dinâmicos, prospectivamente orientados [...]” (CANOTILHO, 1998, p. 1040), especialmente para o a valorização do trabalho humano e da livre iniciativa.

\footnotetext{
1 Ainda que não seja objeto deste trabalho, nunca é demais distinguir os conceitos de emprego e de trabalho, entre relação de trabalho e relação de emprego. Para Maurício Godinho Delgado (2007, p. 285), a relação de trabalho se compreende genericamente, e se refere ao universo de relações jurídicas caracterizadas por uma obrigação de fazer (trabalho em sentido amplo). Por sua vez, consiste em relação de emprego, ainda nas lições do preclaro doutrinador, é uma das modalidades de relação de trabalho. Como espécie deste gênero (trabalho), o emprego é a forma de prestação de trabalho mais importante no sistema econômico contemporâneo, especialmente nos que se baseiam em elementos do sistema econômico capitalista. Os artigos $2^{\circ}$ e $3^{\circ}$ da CLT, com precisa objetividade, definem empregado e empregador e, ato contínuo, caracteriza fática e juridicamente a relação de emprego (prestação de trabalho por pessoa física, não eventual, com pessoalidade, efetuada sob subordinação do tomador dos serviços e com onerosidade).
} 
Conforme aponta em recente artigo Roseli Santos (2015, p. 5266),

O princípio da busca do pleno emprego constituise, no Ordenamento Jurídico Brasileiro, como um direito social constitucional a ser observado no desenvolvimento da atividade econômica e tem como fundamento a valorização do trabalho humano e a justiça social.

O princípio da busca pelo pleno emprego na Constituição Federal de 1988 foi baseado nas ideologias de John Maynard Keynes, economista britânico que na primeira parte do século XX promoveu uma verdadeira revolução no pensamento econômico. Formulando teorias que explicitavam a necessidade de intervenção do Estado na economia, como principal meio de promover o efetivo desenvolvimento socioeconômico.

Nas palavras de José Carlos de Assis (2002, p. 17), o pleno emprego decorre de uma democratização das relações de trabalho e pode ser definido como uma condição do mercado onde todos os que são aptos a trabalhar, e estão dispostos a fazê-lo, encontram trabalho remunerado.

\subsection{Efetivação do Princípio do Pleno Emprego}

Segundo Assis (2000, p. 119), o instrumento fundamental para a promoção do pleno emprego deve passar, necessariamente, por uma mudança de política econômica monetária e de política fiscal. Evidentemente, que issoestá sujeitoà mobilização permanente da opinião pública, de ações efetivas a partir das lideranças políticas, a fim de que possam, a seu tempo e em seus parâmetros, implementar uma ação concreta. 
Deste modo, sintetiza Santos que:

Atualmente discute-se a adequação do termo pleno emprego à realidade social. Numa acepção mais restrita, o pleno emprego seria definido como uma situação em que todos aqueles que estivessem aptos a trabalhar estariam sujeitos a uma relação de emprego. Hoje, com as mais diversas formas de exercício de atividade laboral e de vinculação com os agentes titulares dos meios de produção, a expressão pleno emprego revela um sentido restritivo, sendo mais adequado diante dessa nova realidade socioeconômica, a substituição de seu termo por pleno trabalho ou plena atividade (SANTOS, 2015, p. 5254).

Evidentemente, a busca do pleno emprego figura como um princípio da ordem econômica, consagrando a perspectiva de valorização do trabalho humano e da livre iniciativa de modo a assegurar a todos a existência digna, e se materializando como princípio diretivo da economia. Tem como objetivo a redução gradual e progressiva da desigualdade social decorrente do alto desemprego contemporâneo, tido como um fenômeno estrutural associado ao rápido desenvolvimento tecnológico das últimas décadas (ASSIS, 2002, p. 13-14).

Por conseguinte, a implementação de políticas de pleno emprego aferirá como resultado direto imediato a progressiva eliminação das desigualdades socio-econômicas, da pobreza e o aumento dos salários reais. Indiretamente, conforme Santos (2015, p. 5255 e 5256), o pleno emprego "[...] contribui para a melhoria das condições de trabalho, a recuperação da infraestrutura econômica, a melhora das finanças públicas, o incremento na competitividade externa e o aumento de qualidade nos serviços públicos essenciais". 
Segundo Santos (2015) o êxito de uma política de pleno emprego depende diretamente da atuação de agentes desenvolvedores de atividade econômica - empresários, sendo assim, um programa de promoção de pleno emprego requer a intervenção estatal no sentido de remover entraves econômicos. Assis (2000, p. 119), defende que o instrumento fundamental para a promoção do pleno emprego é a mudança de política econômica monetária e de política fiscal, que depende da mobilização constante da opinião pública e da capacidade das lideranças políticas de implementar uma ação concreta.

Maestro Buelga (2002, p. 65) cita como exemplo, as intervenções destinadas a influenciar diretamente a demanda e a oferta, instrumentadas através de mecanismos tributários e creditícios. E acrescenta que as políticas de mudanças públicas introduzem a possibilidade de influenciar no comportamento dos entes privados e no comportamento do sistema

\subsection{Pleno Emprego e a Preservação da Sociedade Empresária}

Ora, em vista dos argumentos acima, a busca do emprego e, consequentemente, a realização do "pleno emprego", está relacionada estritamente com o princípio da preservação da sociedade empresária. Por isso que, direta e imediatamente, a sociedade empresária e, especialmente, sua preservação e incentivo, interessa ao direito e à economia, pela proteção que oferece à continuidade dos negócios sociais (FACHIN, 2001, p. 199). Decerto, o exercício da atividade empresária é respeitável fonte de tributos e empregos.

Continuamente, o princípio da busca do pleno emprego corresponde ao da preservação da sociedade empresária (de que é corolário o da recuperação da sociedade empresária), segundo o qual, 
diante das opções legais que conduzam a dúvida entre aplicar regra que implique a paralisação da atividade empresária e outra que possa também prestar-se à solução da mesma questão ou situação jurídica sem tal consequência, deve ser aplicada essa última, ainda que implique sacrifício de outros direitos também dignos de tutela jurídica (GONÇALVES NETO, 1998, p. 99).

Constata-se, portanto, que o legislador constituinte, de maneira categórica, pretende evitar que a iniciativa econômica privada possa ser desenvolvida de maneira prejudicial à promoção da dignidade da pessoa humana e à justiça social. Rejeita, igualmente, que os espaços privados, como a família, a sociedade empresária e a propriedade, possam representar uma espécie de zona franca para violação do projeto constitucional (TEPEDINO, 2003, p. 118).

Nesse diapasão, Gama e Cidad (2007, p. 25) defendem que a dignidade é valor próprio e extrapatrimonial da pessoa humana, especialmente no contexto do convívio na comunidade, como sujeito moral. Não há dúvida de que todos os interesses têm como centro a pessoa humana, a qual é o foco principal de qualquer política pública ou pensamento, sendo imperioso harmonizar a dignidade da pessoa humana ao desenvolvimento da sociedade e, consequentemente, do progresso científico e tecnológico. Porquanto, este deve inclinar sempre a aprimorar e melhorar as condições e a qualidade de vida das pessoas humanas, e não o inverso.

A compreensão dos motivos que conduziram o legislador constituinte a estabelecer a busca do pleno emprego como um dos elementos basilares da sistemática jurídica brasileira é bastante simples, pois é a atividade laboral que confere ao trabalhador a remuneração que por ele será utilizada para a digna subsistência sua e de sua família 
(NITSCHKE JÚNIOR, 2008, p. 24). Ou melhor, visa a todos que estejam aptos de forma igual a disputarem os mesmos cargos empregatícios. Este princípio se funda que todo aquele que se encontre apto a trabalhar, estariam sujeitos a uma relação de emprego. Ferreira Filho (1998, p. 356), atribui como significado a criação de oportunidades de trabalho, para que todos possam viver dignamente, do próprio esforço.

Então, mais uma vez é atribuído a empresa e ao governo o dever de incentivar a geração de postos de trabalho, fazendo com que maior parte da população encontre vagas disponíveis, diminuindo o desemprego e como consequência, a desigualdade social do país. Porém, em uma sociedade capitalista tal qual se encontra hoje, com um mercado de trabalho cada dia mais afunilado e acirrado devido as exigências para se qualificar, este principio se torna de um caráter utópico, se não houver uma maior intervenção estatal em inúmeros setores, desde o educacional até o de qualificação ocupacional.

\section{DA FUNÇÃO SOCIAL À FUNÇÃO SOLIDÁRIA DA EMPRESA}

A Constituição de 1988 e o Código Civil de 2002 apresentam as disciplinas gerais da atividade empresarial, sempre à luz de objetivar o alcance do bem social, do bem comum. De fato, a atividade empresarial subordina-se aos preceitos decorrentes do diálogo entre a Constituição e o Direito Civil. Assim, conforme Reale (2005, p. 262), a empresa, assim com o direito privado como todo, desenvolverem as relações e âmbitos atingidos e resguardados pelos Direitos Fundamentais.

Ora, dentre os Direitos Fundamentais de índole constitucionalcivilista, encontra-se o princípio da função social, especialmente aplicada aos contratos. Nos termos de Carvalho (2011, p. 1), função social é “[...] 
categoria programática de ação que tem por escopo cumprir o catálogo de valores, bens e direitos presentes na ordem jurídica". De outro modo e particularmente no âmbito do Direito Contratualista, os dispositivos que partem da ideia de função social são aqueles que permitem às relações jurídicas, mormente as intersubjetivas, adjetivarem-se como probas, de boa-fé, e sem o escopo de acarretar dano a outrem².

Comparato (1990) entende a função social como um poder de agir sobre a esfera jurídica alheia, no interesse de outrem, jamais em proveito do próprio titular. Algumas vezes, interessados no exercício da função são pessoas indeterminadas e, portanto, não legitimadas a exercer pretensões pessoais e exclusivas contra o titular do poder. É nessas hipóteses, precisamente, que se deve falar em função social ou coletiva, e estender os efeitos desta consideração ao ramo da atividade empresarial: em suma, tratar, seria e especificamente, de uma função social da empresa.

A função social da empresa encontra-se inserida no conjunto dos fundamentos da República Federativa do Brasil, dispostos no art. $1^{\circ}$, no artigo $3^{\circ}$, que dispõe sobre os objetivos fundamentais do Estado brasileiro, e no artigo 170, que estabelece como fundamentos da ordem econômica a valorização do trabalho humano e a livre iniciativa, cuja finalidade é a de assegurar a todos uma existência digna, conforme os ditames da justiça social.

Esclarecendo ainda mais, a função social da sociedade empresária encontrou respaldo no supracitado art. 170, III, da Constituição Federal, que o instituiu como princípio da ordem econômica. Segundo Cavallazzi Filho (2006, p. 153), a função social é devida vez que a sociedade

2 A função social e a boa-fé objetiva são princípios fundamentais do Código Civil 2002, conforme intenção expressa por seus idealizadores e descrita na Exposição de Motivos do referido diploma legal, contando, ainda, com o relevo dado nos artigos 186 e 927 e seguintes. 
empresária atua não apenas para atender aos interesses dos sócios, mas de toda a coletividade e principalmente dos empregados, finaliza (COMPARATO, 1990).

Nesse sentido, para Carvalhosa (1977, p. 237) a sociedade empresária tem uma óbvia função social, nela sendo interessados os empregados, os fornecedores, a comunidade em que atua e o próprio Estado que dela retira contribuições fiscais e parafiscais. Para o autor, existem três principais funções sociais da sociedade empresária: a primeira refere-se às condições de trabalho e às relações com seus empregados; a segunda volta-se ao interesse dos consumidores; a terceira volta-se ao interesse dos concorrentes. E ainda mais atual é a preocupação com os interesses de preservação ecológica urbana e ambiental da comunidade em que a sociedade empresária atua.

Com o mesmo raciocínio, Gama (2007, p. 28) e Barcellos (2002, p. 110-113) apontam que, a função social do direito civil, como uma das exigências fundamentais do Estado brasileiro, é um aspecto componente do aparato de proteção que se dá ao princípio da dignidade da pessoa humana, no sentido de viabilizar a consolidação efetiva dos princípios de igualdade material e justiça social.

Ainda no que diz respeito à função social da sociedade empresária, registra Tokars (2002, p. 77-96), que a função social significa um paliativo retórico aos efeitos concretos de nossas políticas econômicas, ou seja, traduz uma válvula de escape psicossocial, a qual pode ser definida como instrumento de aparente conquista social que, na realidade, acaba por atuar exatamente de forma oposta, mantendo privilégios ou impedindo a real conquista dos interesses sociais.

A função social da sociedade empresária se vincula, pois, de sorte imediata, à atividade empresária desenvolvida. 
Quanto à função social da sociedade empresária, anota a doutrina pátria a divisão em duas espécies: endógena e exógena, levando em conta os fatores envolvidos tanto na sociedade empresária quanto em seus métodos para cumprir sua função social.

A função social de caráter endógeno diz respeito aos fatores empregados na atividade empresária no interior da produção. Assim, fazem parte dessa espécie as relações trabalhistas desenvolvidas no âmbito empresário; o ambiente no qual o trabalho é exercido; os interesses dos sócios da sociedade empresária não implícitos na relação administradores-sócios etc.

Por sua vez, a função social da sociedade empresária em seu perfil exógeno leva em conta os fatores externos à atividade desenvolvida pela sociedade empresária. Nesse sentido, são compreendidos nessa espécie de incidência da função social da sociedade empresária: concorrentes, consumidores; e, o meio ambiente (AMARAL, 2008, p. 119).

A título de demonstração de que tanto o perfil exógeno quando o endógeno foram levados em conta pelo legislador constituinte, para Amaral (2008, p. 120), faz-se imprescindível a transcrição do texto do art. 170 da Constituição Federal, asseverando-se que tal preceito abre as disposições constitucionais acerca da ordem econômica no Estado brasileiro.

O caput do art. 170 da Constituição Federal traça os limites que deverão ser obedecidos na aplicação dos princípios que integram seu rol, ao delimitar objetivo relativo à existência digna de todos os brasileiros, devendo ser levados em conta os ditames da justiça social, isto é, de uma justa organização social dos componentes da sociedade, numa expressa referência ao direito como instrumento social. Também há que se afirmar que a ordem econômica deve ser explicitamente fundada na valorização 
do trabalho humano e na livre iniciativa.

Amaral (2008, p. 120-121) acrescenta ainda que, a transcrição do preceito não só demonstra a preocupação do constituinte com a construção de uma sociedade justa e igualitária, como traz à baila o fato de que, ao serem previstos diversos princípios aplicáveis à ordem econômica, cada um deles deverá ter a mesma importância, mas poderá se moldar mais adequadamente à determinado caso concreto.

Verifica-se, pois, que os fatores exógenos e endógenos da atividade empresária estão presentes em tal artigo da Carta Magna. Por certo, a valorização do trabalho humano, sob o ponto de vista empresário, encontra-se dentre os fatores endógenos da função exercida pela sociedade empresária. No que se refere ao meio ambiente, aos consumidores etc., tem-se expressa preocupação do legislador constituinte com fatores exógenos à função social da sociedade empresária, vez que voltados à coletividade na qual a mesma exerce suas atividades (AMARAL, 2008, p. 121).

Quanto às outras importantes atuações da função social da sociedade empresária, Brevidelli (2000, p. 5) explica que seus reflexos sobre o contrato de trabalho que também são evidentes; neles, impõe-se a incidência de outro princípio a reger o contrato: a boa-fé objetiva que, por sua vez, pode ser entendida sob dois enfoques: o subjetivo e o objetivo.

Outrossim, há reflexos da função social no âmbito do direito laboral. Para Brevidelli $(2000$, p. 6) toda a essência da relação de trabalho e a proteção do trabalhador pode ter uma nova dimensão e parâmetro dentro desse novo pensar da sociedade empresária. A questão do trabalho e até mesmo da efetividade do processo do trabalho, perpassa a maneira como se estruturam as sociedades empresárias, como o Direito as conforma e como permite ou não brechas para que as obrigações empresárias 
contraídas e os deveres contratuais não sejam cumpridos, favorecendo a instabilidade social, a concentração de riquezas e aumentando o fosso da injustiça social.

A função social da sociedade empresária, portanto, acarreta a superação do caráter eminentemente individualista, devendo o direito individual do seu titular coexistir com a funcionalização do instituto, desempenhando, pois, um papel produtivo em benefício de toda a coletividade. A atividade empresária, então, apresenta um caráter dúplice, uma vez que serve não só ao sujeito proprietário, como também às necessidades sociais (CASTRO, 2007, p. 138). A função social da sociedade empresária, então, constitui-se em linha mestra do direito de empresa no Código Civil, o que reforça a opinião da preservação da sociedade empresária como princípio essencial desse diploma legal.

Tem-se, então, que a busca da concretização de uma sociedade mais justa e solidária, com a efetiva participação da sociedade, exige a preservação das sociedades empresárias que adotem uma postura positiva no tocante à concretização dos direitos sociais. Essa responsabilidade e dever social das sociedades empresárias, por sua vez, não afastam os deveres inerentes ao Estado. Ao contrário, incumbe ao Estado não só concretizar políticas públicas destinadas à moradia, segurança, saúde e educação, como também, evitar práticas anticoncorrenciais de determinados grupos de sociedades empresárias. Estado e sociedade empresária, portanto, não mais atuam em setores distintos. Na verdade, se completam (CASTRO, 2007, p. 143).

A função social da empresa exige desta uma atividade voltada para os objetivos relacionados ao interesse coletivo. Não implica somente no cumprimento efetivo das obrigações legais e na observância dos direitos mais efetivos da sociedade empresária, como as questões 
sociais, direitos trabalhistas e tributários. Aqui, realiza-se a função social. Entretanto, além da função social, há também a função solidária, pois a empresa também se responsabiliza no compromisso com a preservação ambiental, relacionamento ético com fornecedores e consumidores, bem como o cuidado com o impacto de sua atuação na comunidade onde está inserida.

Assim, alargando o horizonte da função social, encontra-se a função solidária, pela qual se exige por parte da atividade empresária a adoção de operações e interferências na vida social afinadas aos valores éticos, valorizando os princípios dos direitos fundamentais relacionados ao trabalho. Ademais, pela função solidária, as empresas determinam suas ações pelo uso racional dos recursos naturais, na transparência de relações e no cuidado com a coisa pública e com os direitos e deveres que deste espaço decorrem.

Conforme expressam precisamente Campello e Santiago (2015), foi a partir da nova dimensão dos Direitos Humanos, a terceira, que se possibilitou uma subsunção dos direitos de primeira e segunda dimensão, ou seja, os individuais de liberdade e os sociais de igualdade, com os direitos de solidariedade, cujo sujeito é difuso. Nesse sentido:

O fundamento dos direitos de solidariedade está numa nova concepção de Estado, de ordem internacional e de relacionamento entre os povos, mas também - e principalmente - na realização efetiva dos direitos anteriores, a que se somam novos direitos não mais individuais ou coletivos, mas difusos. Nesta ótica, o respeito à soberania de um Estado deve compatibilizar-se com seu dever de cooperar com os demais, o que implica admitir como válidos direitos reconhecidos pela comunidade internacional - leia-se, pela consciência humana (SILVEIRA; 
ROCASOLANO, 2010, p. 177 apud SANCHES; SILVEIRA, 2013, p. 114).

E explicam os autores

Assim, os direitos de solidariedade expressamse como direito à paz, meio ambiente sadio, autodeterminação dos povos e desenvolvimento econômico. O direito ao meio ambiente e ao desenvolvimento econômico são unificados por muitos autores como direito ao desenvolvimento sustentável. $\mathrm{O}$ direito ao meio ambiente sadio e ao desenvolvimento econômico foram unificados, por muitos autores, como direito ao desenvolvimento sustentável. Em um mundo globalizado e em um contexto econômico de capitalismo avançado há um número cada vez maior de situações e condutas humanas que exigem do Estado ações de proteção e de prestação (SANCHES; SILVEIRA, 2013, p. 114).

Portanto, não basta para a atividade empresarial o cumprimento das leis. A sociedade exige mais das empresas: exige ao exercício pautado na função solidária, para enfrentar, combater ou minimizar as consequências sociais do poder das empresas, especialmente em relação aos impactos que suas atividades acarretam nas esferas políticas, econômicas, sociais e ambientais.

Quer dizer que a atividade empresarial deve efetivas ações sustentáveis, solidárias, em vista do maior bem coletivo possível. $\mathrm{Na}$ leitura constitucional dos princípios que regem a empresa, é fundamental destacar que a empresa seja promotora de atividades benéficas e extremamente garantidoras de direitos dos cidadãos, especialmente assegurando a dignidade de vida e a promoção de sadias relações sociais. 
Em nosso país (...) as funções sociais e solidárias das empresas orientam para que elas não sejam aceitas simplesmente como entidades focadas na "maximização auto interessada do lucro, mas que sejam estruturas cujas atividades sejam projetadas para promover e beneficiar as sociedades e os indivíduos com quem interagem (SANCHES; SILVEIRA, 2013, p. 124).

\section{O PLENO EMPREGO E A FUNÇÃO SOLIDÁRIA NA RECUPERAÇÃO DE EMPRESAS}

\subsection{A Lei n.11.101/2005, Lei de Recuperação de Empresas (LRE)}

A centralidade da função solidária da atividade empresarial é fundamental para a efetivação dos direitos fundamentais e sociais, como já visto. Dentre estes, destaca-se a questão do emprego e a mantença da ordem econômica e do exercício digno da vida social. Pela função solidária, as empresas superam as preocupações particulares e se abrem para serem instrumento eficaz para o desenvolvimento econômico do país.

Com a promulgação da Lei $n^{\circ} 11.101$, de 9 de fevereiro de 2005 que passou a viger a partir do mês de junho de 2005, houve a regulamentação da recuperação judicial, da extrajudicial e da falência do empresário e da sociedade empresária. Ela se aplica à execução concursal (e aos meios de evitá-la, que passam a ser a recuperação judicial e a extrajudicial) do devedor sujeito às normas do direito empresário, cuja base inicial teórica do direito de empresa encontra suas premissas básicas no livro II da Parte Especial do Código Civil de 2002.

Dentre tantos elementos inaugurados pela Nova Lei de Falências, são por demais relevantes os dois grandes institutos da recuperação 
judicial e extrajudicial de empresas ${ }^{3}$. Tais institutos vieram substituir o mecanismo de concordata, presente anteriormente à Lei 11.101, e ao substituir, conseguiram estabelecer sob o aspecto econômico um sistema de insolvências com soluções mais possíveis, céleres e eficazes.

A própria lei determina, ao falar sobre a recuperação judicial em seu artigo 47, que a recuperação tem como objetivo:

[...] viabilizar a superação da crise econômicofinanceira do devedor, a fim de permitir a manutenção da fonte produtora, do emprego dos trabalhadores e dos interesses dos credores, promovendo, assim, a preservação da empresa, sua função social e o estimulo à atividade econômica.

Em outros termos, não a citada lei conseguiu objetivar a função social da empresa pois permite, antes de declarar a inviabilidade de atividade empresarial com suas nefastas consequências sociais, realizar certas condições de manutenção de toda a atividade. Ora, há de ressaltar que, com esta lei estabelecimentos, sociedades empresárias e atividades afins continuarão cumprindo a sua função social, especificamente concretizada na geração e preservação de empregos, renda, recolhimento de tributos, produção de riquezas e propulsoras de desenvolvimento econômico social.

Conforme sintetiza André Luiz Santa Cruz Ramos (2013, p. 715), a denominada Lei de Recuperação de Empresas, em seus

3 Em linhas gerais, trata a recuperação judicial a superação de crise econômico-financeira do devedor, permitindo a manutenção da fonte produtora, do emprego dos trabalhadores e dos interesses dos credores. Por estes elementos, fica clara a promoção de questões de forte caráter socioeconômico, como, a preservação de empregos e trabalhos, bem como dos direitos dos trabalhadores, dos interesses dos credores. Por sua vez, a recuperação extrajudicial é a o mecanismo hábil para que, uma vez preenchidos os requisitos legais, venha o devedor propor e negociar com os credores planos de recuperação extrajudicial, tendo também como objetivos os mesmos traçados para a recuperação judicial. 
dispositivos, "[...] deixa claro a sua finalidade: permitir a recuperação dos empresários individuais e sociedades empresárias em crise, em reconhecimento à função social da empresa e em homenagem ao princípio da preservação da empresa".

Entendeu o legislador que mantendo a fonte produtora preservam-se os empregos dos trabalhadores e os interesses dos credores, aqui vistos como interesses imediatos ligados diretamente aos recebíveis e interesses mediatos relacionados com a perenização do fornecimento de produtos ou serviços em contribuição direta do credor para a recuperação e preservação da sociedade empresária.

Equivale dizer, para Almeida (2006, p. 527), que o objetivo da lei é o de permitir a adoção de mecanismos que, pondo em relevo os aspectos inequivocadamente institucionais da empresa viável, busquem sua reorganização e recuperação econômica, com a consequente preservação de empregos, sem prejuízo da produção e circulação de riqueza. Para a Lei ${ }^{\circ} 11.101 / 2005$, empresas viáveis são aquelas que reúnem os requisitos subjetivos e objetivos previstos nos artigos $47 \mathrm{e}$ 48 (recuperação judicial) e 161 (recuperação extrajudicial) e que ainda de acordo com o art. 53 possuam as condições de observar os requisitos do plano de recuperação judicial.

Assim, de modo geral, a regra inspiradora de toda a Lei de Recuperação de Empresas é realizar a função social da empresa seguindo sempre o princípio da preservação da empresa.

Conforme expressa:

O sistema de recuperação de empresas instituído pela nova lei, seguindo a tendência do direito estrangeiro, especialmente do francês e do norte americano nos quais são amplas as possibilidades de recuperação da 
empresa em crise, mediante a direta participação e fiscalização dos credores 126 , e pautado pelas atuais necessidades econômicas, tem como principal foco exatamente a continuação da atividade exercida pelo empresário ou sociedade empresária em crise. Assim, o próprio texto legal é explícito ao determinar, em seu artigo 47, os objetivos da recuperação judicial como sendo viabilizar a superação da situação de crise econômico-financeira do devedor, a fim de permitir a manutenção da fonte produtora, do emprego dos trabalhadores e dos interesses dos credores, promovendo, assim, a preservação da empresa, sua função social e o estímulo à atividade econômica (CAMINHA, MARINHO, 2013, p. 134).

Ora, a aplicação dos elementos legais, sem dúvida, possibilita atingir, assim, a função socio-solidária da sociedade empresária e o fomento da atividade econômica. Haja vista os grandes avanços obtidos pela nova legislação, que vieram ao encontro desta função solidária. Destaque-se, primeiramente, a própria preservação da empresa que, conforme já expresso, é o principal fundamento da lei ao compreender especifica e objetivamente a função social da empresa, uma vez que ela é fonte geradora de riqueza, emprego e renda ${ }^{4}$.

Ao lado disto, importante frisar outros ganhos que a LRE trouxe, como a recuperação das sociedades e empresários recuperáveis como múnus do Estado, já que este deve dar condições para recuperação da empresa e a ampla proteção aos trabalhadores, uma vez que estes terão preferência no recebimento de seus créditos na falência e na recuperação.

4 "Tatiana Bautzer, na publicação eletrônica da revista EXAME, faz uma avaliação em que: 'Estima-se que, das cerca de 4000 empresas que pediram recuperação no país desde a entrada em vigor da nova lei, só $1 \%$ delas tenha saído do processo recuperadas de fato, segundo dados da consultoria Corporate Consulting. Pouco mais de $10 \%$ faliram e o restante continua sob a tutela dos administradores mesmo depois dos dois anos vistos por especialistas como razoável para concluir uma recuperação judicial"'. Disponível em https://jus.com.br/artigos/42295/10-anos-da-lei-de-falencias-e-recuperacao-de-empresas. Acesso em: 2 out. 2016. 
Por fim, a LRE contempla as micro e pequenas empresas, realidade tão presente na atividade econômica do Brasil, como artigos e procedimentos que centralizam-se na desburocratização a favor da recuperação judicial ${ }^{5}$.

\subsection{Elementos fundamentais para compreensão da LRE}

Para Santos (2006), verifica-se no processo falimentar um tratamento diferenciado que confere aos contratos em que seja parte o empresário falido. Os contratos recebem tratamento jurídico diferenciado e são afastadas as regras específicas do direito civil, direito do consumidor e direito empresarial. A disposição geral sobre os contratos na falência autoriza a resolução dos bilaterais não cumpridos e dos unilaterais (arts. 117 e 118 da Lei $n^{0} 11.101 / 2005$ ) por decisão do administrador judicial autorizado pelo comitê de credores que poderá exercer o juízo de conveniência e oportunidade quanto ao cumprimento ou a resolução dos contratos bilaterais não cumpridos ou unilaterais.

No entendimento de Coelho (2005, p. 315) é condição para a rescisão que nenhuma das partes tenha dado início, ainda, ao cumprimento das obrigações assumidas, ou seja, unilateral o contrato. Excluem-se do âmbito do preceito, portanto, e da possibilidade de serem rescindidos pela decretação da falência, os contratos que, embora definidos como bilaterais pelo direito obrigacional comum, já tiveram a sua execução iniciada por qualquer uma das partes.

Em suma, a falência do contratante pode provocar a rescisão do contrato em que ambas as partes assumem obrigações se a sua execução ainda não teve início por nenhuma delas e daquele em que somente uma das partes (unilaterais) se obrigou. Se a falida ou o outro contratante já

5 Cf. maiores detalhes na análise atenta e fundamentada de Paulo Roberto Arnoldi (ARNOLDI, 2006, p. 79-87).

SCIENTIA IURIS, Londrina, v.21, n.1, p.212-244, Mar.2017 DOI: 110.5433/2178-8189.2017v21n1p212 
haviam iniciado a execução do contrato bilateral, cumprindo parcial ou totalmente as obrigações contraídas, a falência não poderá importar a rescisão. Entretanto, nos contratos interempresariais, costuma constar do instrumento a expressa previsão de rescisão na hipótese de falência de um ou qualquer dos contratantes. Se as partes pactuaram cláusula de rescisão por falência, esta é válida e eficaz, não podendo os órgãos da falência desrespeitá-la. Assim, o contrato se rescinde não por força do decreto judicial, mas pela vontade das partes contratantes, que o elegeram como causa rescisória do vínculo contratual, conclui Coelho (2005, p. 317).

Campinho (2006, p. 352), defende a possibilidade de continuidade das relações de trabalho, mesmo durante o processo falimentar. Melhor explicando, os contratos de trabalho cujo empregador é o falido não se resolvem com a falência, uma vez que somente com a cessação das atividades da sociedade empresária é ocorrerá causa resolutória desses contratos. $\mathrm{Na}$ hipótese de continuidade da relação de trabalho na falência, subsistem ao empregado os direitos advindos da existência do contrato de trabalho (art. 449, CLT) e os créditos dele decorrentes terão prioridade entre os credores concursais até o limite de 150 (cento e cinquenta) salários mínimos (art. 83 da Lei no 11.101/2005). Também o art. 141 da Lei $n^{\circ} 11.101 / 2005$ preceitua que:

$\mathrm{Na}$ alienação conjunta ou separada de ativos, inclusive da empresa ou de suas filiais, promovida sob qualquer das modalidades de que trata este artigo.

[...] II - o objeto da alienação estará livre de qualquer ônus e não haverá sucessão do arrematante nas obrigações do devedor, inclusive as de natureza tributária, as derivadas da legislação do trabalho e as decorrentes de acidentes de trabalho.

$\S 2^{\circ}$ - Empregados do devedor contratados pelo 
arrematante serão admitidos mediante novos contratos de trabalho e o arrematante não responde por obrigações decorrentes do contrato anterior.

Para Santos (2006) esse dispositivo otimiza e incentiva a aquisição de toda a estrutura empresarial (recursos materiais e imateriais empregados) para que um outro agente econômico possa explorar é o fim da sucessão empresarial na alienação do estabelecimento para os débitos de qualquer natureza, inclusive os trabalhistas e tributários, tanto na falência como na recuperação judicial. Como afirmado, o vínculo trabalhista entre o adquirente da empresa do falido e os empregados que continuarem trabalhando naquela atividade econômica é novo e as obrigações do antigo empregador não podem ser cobradas do adquirente estimulando os agentes econômicos na aplicação do princípio da busca do pleno emprego, a partir da preservação dos contratos de trabalho bem como do princípio da função social da empresa.

Ressalva-se, segundo Coelho (2005, p. 367), a situação de adquirentes que estejam agindo em nome e por conta de um ou mais sócios da sociedade empresária quebrada. Quer dizer, se quem arrematou a empresa ou ativos da falida tiver alguma ligação com os empreendedores e investidores desta, a sucessão se estabelece. Tratase de dispositivo destinado a evitar fraudes no manuseio de instituto jurídico de real importância para obtenção dos recursos necessários ao atendimento dos direitos dos credores. Não são beneficiados pela regra de supressão da sucessão, portanto, o sócio da falida (controlador ou não), seu parente, sociedade controladora ou controlada desta ou quem, por qualquer razão, for identificado como agente do falido. 


\section{CONCLUSÃO}

A atividade empresária possui especial relevância para o desenvolvimento das sociedades contemporâneas vez que fonte geradora de empregos e de recolhimento de impostos e contribuições sociais, organizada para a produção ou a circulação de bens ou de serviços. Ao desempenhar essa atividade, funciona como mecanismo de inclusão social, de promoção da dignidade da pessoa humana e de inserção no mercado de trabalho de todos aqueles que são aptos a trabalhar e estão dispostos a fazê-lo para encontrar trabalho remunerado competindo ao Estado promover condições macroeconômicas de pleno emprego, mediante a manipulação das políticas fiscal e monetária.

Daí é forçoso afirmar que todo o Direito brasileiro, especialmente sua vertente Civil-Constitucionalista, esperadas empresas não só a responsabilidade social, e sim, a fortiori, a responsabilidade solidária. Por ela, a empresa se vê vinculada a dizer e fazer algo referente não só à busca de lucro ou profissionalidade econômica, mas a tudo aquilo que promova o bem comum em relação às pessoas e ao meio ambiente.

Entretanto, Assis (2002, p. 20-21) chama a atenção para o fato de que, o direito ao trabalho remunerado, mesmo quando protegido constitucionalmente, não tem uma contrapartida específica que obrigue que ele seja satisfeito pelo setor privado ou pelo setor público empregador. Ele se traduz, analiticamente, como direito coletivo a uma política publica de promoção ao pleno emprego. Certamente, só o Estado dispõe de instrumentos de política econômica para criar condições favoráveis ao pleno emprego no mercado de trabalho. São políticas do lado da oferta (treinamento e reciclagem de mão-de-obra) e, principalmente, do lado da demanda (gastos e déficit fiscal para financiar os investimentos públicos, 
redução da taxa de juros, redução da carga tributária, obras públicas, subsídios e incentivos a investimentos privados, oferta de empregos públicos, reforma agrária).

O princípio da busca do pleno emprego, como um princípio regulador da ordem econômica para Santos (2006), encontra amparo e lança seus fundamentos para sua interpretação e aplicação na Lei $n^{\text {o }} 11.101 / 2005$ que reconhece a importância social da empresa, ao proporcionar a sua recuperação tanto judicial como extrajudicial. O princípio utilizado como critério para a utilização do procedimento de falência ou recuperação judicial é a viabilidade e preservação da empresa. Dessa forma, tem por objetivo viabilizar a superação da crise do empresário, permitindo a manutenção da sociedade empresária, dos empregos e dos interesses dos credores, tem por objetivo preservar e otimizar a utilização produtiva dos bens e ativos.

Daí por que para Fazzio Júnior (2005, p. 35), basta a presunção de insolvência da sociedade empresária para justificar a busca de uma solução jurisdicional. O interesse de agir nos processos regidos pela lei falimentar e de recuperação das empresas habita na necessidade de um provimento judiciário apto a dirimir não só a crise econômico-financeira de um empresário, mas também toda sorte de relações decorrente, de modo a preservar, se possível, a unidade econômica produtiva.

Nesse contexto, a Lei n. 11.101, de 09 de fevereiro de 2005, a Lei de Recuperação de Empresas (LRE), foi um marco na evolução do direito brasileiro. Por ela, há de preservar as empresas e toda a função sócio-solidária que dela decorre. De fato, é central a preocupação da Lei em relação à preservação da empresa e da circulação de seus bens e serviços, especialmente na oferta e manutenção de empregos e força econômica ativa dos cidadãos. 
As tensões econômico-financeiras, bem como os desafios sociais em tempos de globalização vêm exigindo por demais das atividades empresárias, bem como as tornaram suscetíveis às mais diversas crises, especialmente às que problematizam da saúde financeira de suas atividades empresariais. Em razão de novas hipóteses e variáveis, a LRE se torna tão importante nos dias atuais.

De fato, por esta legislação, a falência ou a liquidação da empresa se tornam muito mais difíceis, e, desta feita, há de se possibilitar mecanismos que evitem a tragédia social que o fechamento ou extinção de uma atividade empresária pode causar. Assim, os elementos da LRE, especialmente, aquilo que se entende como principal fundamento da leia Preservação da empresa - leva em conta a função solidária da atividade empresarial. Afinal, esta é fonte geradora de riqueza, emprego e renda, meios fundamentais para realizar o princípio do pleno emprego e todos os outros princípios socioeconômicos garantidos pela Constituição Federal.

Assim, é possível reler o texto legal à luz dos princípios do pleno emprego e da função solidária. Ao propor uma intervenção estrutural na atividade empresarial, de modo a mantê-la produtiva, procura o legislador salientar a importância das atividades empresariais para a manutenção e poderio econômicos de todos os cidadãos, de outras empresas e do próprio estado, além, evidentemente, da preservação e desenvolvimento da própria atividade empresária.

\section{REFERÊNCIAS}

ALMEIDA, Amador Paes. Curso de falência e de recuperação de empresa. São Paulo: Saraiva, 2006.

AMARAL, Luiz Fernando de Carmo Prudente. A função social da 
empresa no direito constitucional econômico brasileiro. São Paulo: SRS Editora, 2008.

ARNOLDI, Paulo Roberto Colombo. Balanço do primeiro ano de vigência da nova lei de recuperação brasileira - Lei n. 11.101/05: êxitos e preocupações quanto à solução da crise econômica financeira. Jornadas de Derecho Comercial, 2006, p. 79-87.

ASSIS, José Carlos de. A quarta via: a promoção do pleno emprego como imperativo da cidadania ampliada. São Paulo: Textonovo, 2000.

ASSIS, José Carlos de. Trabalho como direito: fundamentos para uma política de pleno emprego no Brasil. Rio de Janeiro: Contraponto, 2002.

AZEVEDO, Marcelo Cândido de. O Princípio da Função Social e o Direito de Empresa: algumas considerações. In: Cadernos de Direito. Piracicaba, v. 8(15): 35-57, jul./dez. 2008. Disponível em https:// www.metodista.br/revistas/revistas-unimep/index.php/direito/article/ viewFile/454/131. Acesso em 13 de setembro de 2015.

BARCELlOS, Ana Paula de. A eficácia jurídica dos princípios constitucionais:o princípio da dignidade da pessoa humana. Rio de Janeiro: Renovar, 2002.

BRASIL. Lei n. 11.101, de 9 de fevereiro de 2005. Regula a recuperação judicial, a extrajudicial e a falência do empresário e da sociedade empresária. Disponível em: <http://www.planalto.gov.br/ccivil_03/ ato2004-2006/2005/lei/111101.htm>. Acesso em: 27 mar. 2017.

BREVIDELLI, Sheilla Regina. A função social da empresa: alargamento das fronteiras éticas nas relações de trabalho. São Paulo: USP, 2000.

CAMINHA, Uinie; MARINHO, Sara Morganna Matos. A novação na recuperação judicial: análise das peculiaridades da aplicação do instituto 
de direito civil ao direito falimentar. Revista Novos Estudos Jurídicos, Itajaí, v. 18, n. 1, p. 135-150, jan./abr. 2013.

CAMPELO, Gaigher Bosio; SANTIAGO, Mariana Ribeiro (Coord.). Ética, ciência e cultura jurídica: IV Congresso Nacional da FEPODI. São Paulo: FEPODI, 2015

CAMPINHO, Sérgio. Falência e recuperação de empresa: o novo regime da insolvência empresarial. 2. ed. Rio de Janeiro: Renovar, 2006.

CANOTILHO, José Joaquim Gomes. Direito constitucional e teoria da constituição. Coimbra: Almedina, 1998.

. Estudos sobre direitos fundamentais. Coimbra: Coimbra Editora, 2004.

CARVALHOSA, Modesto. Comentários à lei de sociedades anônimas. São Paulo: Saraiva, 1977.

CASTRO, Carlos Alberto Farracha. Preservação da empresa no código civil. Curitiba: Juruá, 2007.

CAVALLAZZI FILHO, Tullo. A função social da empresa e seu fundamento constitucional. Florianópolis: OAB/SC Editora, 2006.

COELHO, Fábio Ulhoa. Curso de direito comercial. 8. ed. São Paulo: Saraiva, 2005a. v. 2.

. Comentários à nova lei de falências e de recuperação de empresas. São Paulo: Saraiva, 2005 b.

COMPARATO, Fábio Konder. Direito empresarial: estudos e pareceres. São Paulo: Saraiva, 1990. 
FACHIN, Luiz Edson. Estatuto jurídico do patrimônio mínimo. Rio de Janeiro/São Paulo: Renovar, 2001.

FAZZIO JÚNIOR, Waldo. Nova lei de falência e recuperação de empresas. São Paulo: Atlas, 2005.

FERREIRA FILHO, Manoel Gonçalves. Direitos humanos fundamentais. 2. ed. rev. e atual. São Paulo: Saraiva, 1998.

GAMA, Guilherme Calmon Nogueira da; CIDAD, Felipe Germano Cacicedo. Função social no direito privado e Constituição. In: Função social no direito civil. São Paulo: Atlas, 2007.

GONÇAlVES NETO, Alfredo Assis. Apontamentos de direito comercial. Curitiba: Juruá, 1998.

MAESTRO BUELGA, Gonzalo. La constitucióndeltrabajonel Estado social. Granada: Comares, 2002.

NITSCHKE JÚNIOR, Ademar. A atividade empresarial no Brasil e a ordem econômica na Constituição Federal de 1988: a necessária harmonia para a promoção do desenvolvimento econômico e redução das desigualdades sociais [Dissertação de Mestrado]. Curitiba: Unicuritiba, 2008.

RAMOS, André Luiz Santa Cruz. Direito empresarial esquematizado. 3. Ed. São Paulo: Método, 2013.

REALE, M. História do Novo Código Civil. São Paulo: RT, 2005.

SANTOS, Roseli Rêgo. O princípio da busca do pleno emprego como aplicação da função social da empresa na Lei de Falências e Recuperação. Disponível em: <http://www.publicadireito.com.br/ conpedi/manaus/arquivos/anais/salvador/roseli_rego_santos.pdf $>$ nov. 
2006. Acesso em: 05mai. 2014. Anais do COMPEDI, 2015.

SILVEIRA, Vladmir Oliveira da; ROCASOLANO, Maria Mendez. Direitos humanos: conceitos, significados e funções. São Paulo: Saraiva, 2010.

SILVEIRA, Vladmir Oliveira da; SANCHES, Samyra. H D. F. N. Direito e Desenvolvimento no Brasil do Século XXI: uma análise da normatização internacional e da Constituição brasileira. In: SILVEIRA, Vladmir Oliveira da; NASPOLINI SANCHES, Samyra. H D. F; COUTO, Mônica Bonetti. (Orgs) Direito e Desenvolvimento. Brasília: IPEA, 2013.

SOUZA, Washington Peluso Albino. Primeiras linhas de direito econômico. São Paulo: LTr, 2003.

TEPEDINO, Gustavo. A constitucionalização do direito civil: perspectivas interpretativas diante do novo código. In: Direito civil: atualidades. Belo Horizonte: Del Rey, 2003.

TOKARS, Fábio Leandro. Função social da empresa. In: Direito civil constitucional: situações patrimoniais. Curitiba: Juruá, 2002.

Como citar: BRASIL, Deilton Ribeiro; MARTINS, Leandro José de Souza. O princípio do pleno emprego: a função solidária e sustentabilidade das sociedades empresárias. Scientia Iuris, Londrina, v. 21 , n. 1, p.212-244, mar. 2017. DOI: $10.5433 / 2178-8189.2017 \mathrm{v} 21 \mathrm{n}$ 1p212. ISSN: 2178-8189.

Recebido em: 13/07/2016

Aprovado em: 30/01/2017 